\title{
Percutaneous lignocaine absorption in newborn infants
}

\author{
D A Barrett, N Rutter
}

\begin{abstract}
The permeability of the skin of newborn infants to lignocaine was examined in vitro using excised skin. Samples were studied from 24 infants of gestational age 25 to 40 weeks and postnatal age 0 to 7 days. Mature skin was relatively impermeable to lignocaine, but the more premature infants showed a marked increase in absorption. There was a strong inverse correlation between gestational age and skin permeability. These findings suggest that topical lignocaine would be an effective local anaesthetic in preterm infants. Calculations indicate that there is negligible risk of toxicity due to systemic absorption.
\end{abstract}

(Arch Dis Child 1994; 71: F122-F124)

Local anaesthetic drugs are poorly absorbed through the skin of adults and children. ${ }^{1}$ Penetration sufficient to achieve local anaesthesia is possible by the use of a eutectic mixture of two drugs, lignocaine and prilocaine, but they need to be applied under an occlusive dressing and left for an hour or more. ${ }^{2}$ This mixture (Emla cream, Astra) is widely used in children before non-urgent venepuncture and has been shown to provide effective anaesthesia. The prilocaine component, however, causes methaemoglobinaemia. ${ }^{3}$ As this is likely to be clinically important in very young children, particularly in preterm infants, Emla is not licensed for use in children less than 1 year of age.

The high permeability of newborn epidermis to many compounds ${ }^{4}$ suggests that topical analgesia could be achieved in preterm neonates by the application of a simple aqueous lignocaine solution. A study was therefore designed to examine the percutaneous absorption of lignocaine using an in vitro skin cell technique and excised skin samples. The aim was to calculate whether sufficient absorption of lignocaine occurs to provide anaesthesia without systemic effects.

Pharmaceutical Sciences, Nottingham University, Nottingham NG7 2RD B A Barrett

Department of Child Health, Nottingham University

N Rutter

Correspondence to: Dr Barrett.

Accepted 31 March 1994
Skin samples were studied from 24 newborn infants, gestational age 25 to 40 weeks, at a median age of 1 day (range 0 to 7 days). Three adult skin samples were studied for comparison.

\section{SUBJECTS}

\section{MATERIALS}

Lignocaine hydrochloride was purchased from Sigma (Poole, Dorset). All other chemicals were of analytical reagent grade or better. Constant ionic strength buffers $(0 \cdot 1 \mathrm{M})$ were used: sodium acetate/acetic acid ( $\mathrm{pH} 4 \cdot 0)$, Sørensen's phosphate buffer ( $\mathrm{pH} \mathrm{5.6-8),} \mathrm{and}$ carbonate/bicarbonate buffer ( $\mathrm{pH} 10 \cdot 7)$.

\section{SKIN PREPARATION AND PERMEABILITY}

\section{EXPERIMENTS}

Excised skin from newborn infants was used in the permeation studies. Samples of whole skin of $2-3 \mathrm{~cm}^{2}$ area were removed at necropsy by abdominal incision within 24 hours of death. The skin samples were wrapped in aluminium foil, sealed in a small plastic envelope, and stored in a freezer at $-30^{\circ} \mathrm{C}$. Before use the frozen skin sections were thawed at room temperature and rehydrated in phosphate buffered saline (PBS) (pH 5.6 with $0.01 \%$ sodium azide to prevent bacterial growth) at $4^{\circ} \mathrm{C}$ for $18-24$ hours before the experiment. The subcutaneous layer of fat was carefully trimmed from the neonatal skin and the intact skin was mounted into the diffusion cell apparatus for the in vitro study.

The epidermal layer of adult skin was separated from the whole skin by suspension in water $\left(60^{\circ} \mathrm{C}\right.$, two minutes), dried at room temperature ( 30 minutes), and stored frozen at $-30^{\circ} \mathrm{C}$ before use. The subsequent experimental procedure was identical to that used for excised neonatal skin.

Each skin section was mounted carefully between the half cells of a side by side diffusion cell of $3.4 \mathrm{ml}$ capacity and with a diffusional area of $0.64 \mathrm{~cm}^{2}$ (Crown Glass Company, USA). The two half cells were firmly clamped together and the receptor half cell (inner, dermal side) was filled with buffer (PBS, pH 5.6) and the donor half cell (outer, stratum corneum side) was filled with lignocaine solution $(10 \mathrm{mg} / \mathrm{ml}$ in $0.1 \mathrm{M}$ acetate buffer $\mathrm{pH} 4.0$ or appropriate buffered $\mathrm{pH}$ ). The jacketed diffusion cells were maintained at $32^{\circ} \mathrm{C}$ using a flow heater (Grant Instruments, Cambridge) and each half cell was stirred throughout the experiment at approximately $100 \mathrm{rpm}$. At predetermined times $0.2 \mathrm{ml}$ aliquots of the receptor content were withdrawn and replaced with equal volumes of fresh buffer. Samples $(0.2 \mathrm{ml})$ were taken from the donor compartment at the beginning of each experiment and at the end of each day of the study to ensure that the depletion of the 
Table 1 In vitro permeation of lignocaine through human neonatal skin

\begin{tabular}{|c|c|c|c|c|}
\hline $\begin{array}{l}\text { Gestational age } \\
\text { (weeks) }\end{array}$ & $\begin{array}{l}\text { Postnatal age } \\
\text { (days) }\end{array}$ & $\begin{array}{l}\text { Apparent permeability } \\
\text { coefficient } \\
\left(\mathrm{cm} / \mathrm{hour} \times 10^{-4}\right)^{\star}\end{array}$ & $\begin{array}{l}\text { Lag time } \\
\text { (hours) }\end{array}$ & $\begin{array}{l}\text { Lignocaine } \\
\text { bound to skin } \\
\left(\mu \mathrm{g} / \mathrm{cm}^{2}\right)\end{array}$ \\
\hline $\begin{array}{l}25 \\
25 \\
25 \\
25 \\
26 \\
26 \\
26 \\
30 \\
32 \\
32 \\
32 \\
33 \\
34 \\
34 \\
34 \\
35 \\
35 \\
36 \\
36 \\
36 \\
36 \\
38 \\
38 \\
40\end{array}$ & $\begin{array}{l}1 \\
1 \\
1 \\
\mathrm{~s} / \mathrm{b} \\
1 \\
7 \\
7 \\
\mathrm{~s} / \mathrm{b} \\
\mathrm{s} / \mathrm{b} \\
\mathrm{s} / \mathrm{b} \\
1 \\
2 \\
1 \\
1 \\
1 \\
1 \\
1 \\
4 \\
4 \\
1 \\
1 \\
\mathrm{~s} / \mathrm{b} \\
\mathrm{s} / \mathrm{b} \\
\mathrm{s} / \mathrm{b}\end{array}$ & $\begin{array}{c}120.0 \\
62.5 \\
67.0 \\
55 \cdot 0 \\
388 \cdot 4 \\
8.5 \\
3.5 \\
19.3 \\
1.0 \\
27 \cdot 0 \\
6.4 \\
6.0 \\
6.6 \\
7 \cdot 4 \\
4 \cdot 4 \\
0.7 \\
0.3 \\
0.5 \\
0.9 \\
2.9 \\
2.6 \\
3.8 \\
0.5 \\
0.044\end{array}$ & $\begin{array}{r}0.5 \\
0.7 \\
<0.5 \\
0.4 \\
<0.5 \\
2.6 \\
0.0 \\
<0.5 \\
0.6 \\
<0.5 \\
<0.5 \\
3.7 \\
1.9 \\
1.9 \\
- \\
- \\
- \\
<0.5 \\
<0.5 \\
2.4 \\
<0.5 \\
<0.5 \\
<0.5 \\
<0.5\end{array}$ & $\begin{array}{r}- \\
- \\
168 \\
72 \\
425 \\
141 \\
52 \\
40 \\
152 \\
486 \\
112 \\
2632 \\
967 \\
940 \\
- \\
209 \\
157 \\
22 \\
384 \\
101 \\
26 \\
24 \\
60 \\
133\end{array}$ \\
\hline \multicolumn{2}{|c|}{ Adult epidermis samples } & $\begin{array}{l}0.9 \\
3 \cdot 4 \\
0 \cdot 3\end{array}$ & & \\
\hline
\end{tabular}

$\mathrm{s} / \mathrm{b}=$ Still born. ${ }^{\star}$ Single determination for each skin sample.

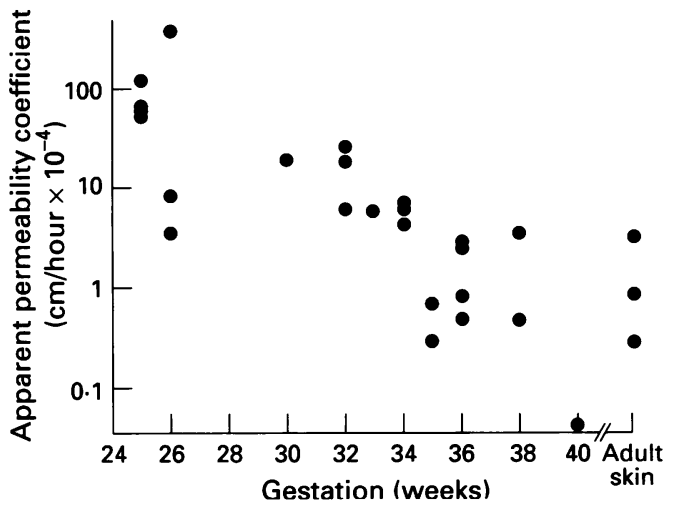

Relation between gestational age and percutaneous

lignocaine absorption in newborn infants.

drug did not exceed $10 \%$ during the course of the study. At the end of the experiment the skin was removed from the apparatus and rinsed twice in $\mathrm{pH} 5.6$ buffer, blotted dry, and then extracted in methanol for 24 hours to remove any lignocaine remaining bound to the skin. The permeation samples and the skin extracts were analysed by high performance liquid chromatography (HPLC) to determine the lignocaine concentration.

\section{ANALYTICAL METHODS}

Lignocaine was determined by HPLC under the following conditions: the column was a Hypersil ODS (Shandon Scientific, Runcorn), $15 \mathrm{~cm}$ long, $4.6 \mathrm{~mm}$ internal diameter with $5 \mu \mathrm{m}$ particle size; the mobile phase comprised $65 \%$ potassium phosphate buffer $(0.05 \mathrm{M})$, $35 \%$ acetonitrile, and $0.1 \%$ triethylamine, adjusted to $\mathrm{pH} 3.0$ with orthophosphoric acid. The flow rate was $1.0 \mathrm{ml} / \mathrm{min}$, the injection volume was $50 \mu \mathrm{l}$, and an ultraviolet absorbance detector (wavelength $220 \mathrm{~nm}$ ) was used. The limit of detection of each compound was $0.02 \mu \mathrm{g} / \mathrm{ml}$ and the assay was linear over the range 0.02 to $100 \mu \mathrm{g} / \mathrm{ml}$.

\section{ANALYSIS OF DATA}

The data were plotted as the cumulative amount of drug collected in the receptor cell versus time. The apparent permeability coefficient for a given run was calculated from Fick's first law:

$$
\mathrm{J}_{\mathrm{T}}=\mathrm{AP} \Delta \mathrm{C}
$$

In this equation $\mathrm{J}_{\mathrm{T}}$ is the total steady state flux of drug in $\mu \mathrm{g} / \mathrm{hour}$; $A$ is the area of the membrane $\left(0.64 \mathrm{~cm}^{2}\right) ; \mathrm{P}$ is the apparent permeability coefficient in $\mathrm{cm} /$ hour and $\Delta \mathrm{C}$ is the concentration difference between the two chambers of the diffusion cell, which was taken as the initial donor phase concentration in $\mu \mathrm{g} / \mathrm{ml}$. The steady state flux was calculated from the slope of the terminal, linear portions of the plot of cumulative lignocaine permeation versus time using linear regression analysis. The lag time was calculated as the intercept of the steady state portion of the curve on the time axis. Lignocaine is present in the donor solution ( $\mathrm{pH} \mathrm{4.0)}$ ) predominantly in its ionised form (lignocaine $\mathrm{pK}_{\mathrm{a}}=7 \cdot 86$ ). A small but significant amount of the unionised drug will be present, however. The proportion of ionised to unionised drug transported depends on the structure of the skin barrier which, in premature neonates, is known to change with gestational age. Hence no attempt has been made to identify the transported species and the calculated permeability coefficients relate to the total lignocaine flux.

The significance of any correlation between the gestational age of the subjects and the parameters of permeation of lignocaine or lag time was tested using Spearman's rank correlation test for non-parametric data.

\section{Results}

Table 1 gives the apparent permeability coefficients (a standardised measure of the permeability of the skin sample) and lag times of lignocaine penetration. A strong inverse relation $(p<0.01)$ exists between the gestational age of the infant and the permeability of skin to lignocaine (figure). The permeability of skin at 25 weeks' gestation was $10^{2}$ to $10^{3}$ times greater than at term. Lignocaine penetration through adult epidermis was similar to that in full term neonates. There was no correlation between gestational age and the amount of lignocaine bound to the skin sample at the end of the in vitro skin cell experiment, and no correlation between gestational age and lag time.

Table 2 shows the effect of $\mathrm{pH}$ on the permeation of lignocaine through neonatal skin. There was a threefold increase in the permeability coefficient at alkaline $\mathrm{pH}$, consistent with the predominance of the unionised form of the drug above its $\mathrm{pK}_{\mathrm{a}}$ value of $7 \cdot 86$.

\section{Discussion}

Lignocaine is known to be poorly absorbed through adult skin and we have showed that it is also poorly absorbed through mature 
Table 2 Effect of pH on the permeation of lignocaine through neonatal skin

\begin{tabular}{rlcc}
\hline & $\begin{array}{l}\text { Apparent permeability } \\
\text { coefficient } \\
\left(\text { cm/hour } \times 10^{-4}\right)\end{array}$ & $\begin{array}{l}\text { Lag time } \\
\text { (hours) }\end{array}$ & $\begin{array}{l}\text { Lignocaine } \\
\text { bound to skin } \\
\left(\mu \mathrm{g} / \mathrm{cm}^{2}\right)\end{array}$ \\
\hline $4 \cdot 0$ & $2 \cdot 6$ & $5 \cdot 1$ & 130 \\
6.8 & $2 \cdot 9$ & $5 \cdot 7$ & 503 \\
$8 \cdot 3$ & 7.9 & $8 \cdot 3$ & 1155 \\
$10 \cdot 7$ & $7 \cdot 2$ & 10.7 & 1172
\end{tabular}

All data from a single piece of excised skin from an infant of 36 weeks' gestation, 1 day postnatal age.

newborn skin. It readily penetrates the much weaker epidermal barrier of preterm infants' skin, however. This has been noted with a number of drugs, including theophylline, salicylate, alcohols, and diamorphine. ${ }^{5-8}$ The epidermal barrier to drug absorption, the keratinised stratum corneum, is poorly developed in preterm infants in the first weeks of life, during which period the infant may be susceptible to toxicity due to topically applied drugs. ${ }^{9}$ The amount of lignocaine which passes through the skin of premature infants is appreciable, and would be sufficient to cause local anaesthesia. It is necessary, however, to consider the potentially toxic effects of the systemically absorbed lignocaine to ensure that the topical lignocaine is safe. It is possible, using a standard pharmacokinetic equation, ${ }^{10}$ to estimate the maximum plasma concentration of lignocaine arising from systemic absorption using the permeability coefficients recorded in this study and assuming a mean plasma clearance value of $9.2 \mathrm{ml} / \mathrm{min} / \mathrm{kg}$ for lignocaine in preterm infants. ${ }^{11}$ In the case of an extremely premature infant of $1.0 \mathrm{~kg}$ body weight and 25 weeks' gestation, lignocaine solution applied to a skin area of $5 \mathrm{~cm}^{2}$ would result in an estimated plasma lignocaine concentration of about $1.0 \mu \mathrm{g} / \mathrm{ml}$. This is below the therapeutic concentration of lignocaine $(1.5-6.0 \mu \mathrm{g} / \mathrm{ml})$ when used as an antiarrhythmic drug and considerably lower than the toxic concentration. For infants of greater maturity the estimated plasma drug concentration would be proportionately lower. This indicates that topical application of the drug is unlikely to lead to unwanted systemic effects. In more mature infants, with lower skin permeability and greater body weight, the estimated systemic absorption is likely to be negligible.

Two of the skin samples from infants of 26 weeks gestation showed a markedly lower permeation than that observed in the other skin samples from premature infants. It is known that the skin of premature infants matures rapidly to reach maturity within 14 to 21 days. ${ }^{9}$ These skin samples were from infants with a postnatal age of 7 days, compared with a median postnatal age of 1 day. It is therefore likely that the skin barrier had partially matured over this postnatal period, providing an explanation for the lower rate of absorption.

The observed increase in the rate of penetration of lignocaine at alkaline $\mathrm{pH}$ is expected as the drug is predominantly in its unionised form above its $\mathrm{pK}_{\mathrm{a}}$ value $(7 \cdot 6)$. It is known that unionised drugs permeate more readily through the lipid barrier of the skin. This result is in agreement with a previous study of the effect of $\mathrm{pH}$ on the penetration of lignocaine through adult human stratum corneum, which reported a threefold increase in lignocaine penetration through adult skin at alkaline pH compared with acid pH. ${ }^{12}$ This $\mathrm{pH}$ dependency of lignocaine penetration could potentially be used as a means of controlling the rate of permeation into skin as the skin has a relatively wide tolerance to $\mathrm{pH}$ (between $\mathrm{pH}$ 4 and 11 ).

The data presented on the binding of lignocaine to skin in vitro indicates that the extent of binding is not dependent on gestational or postnatal age. Hence there is no evidence for the formation of a depot of lignocaine in the skin which may cause difficulties with in vivo studies.

In conclusion, this in vitro study suggests that percutaneous absorption in preterm infants is likely to be sufficient to produce local anaesthesia without causing unwanted systemic side effects. The study provides further evidence of the considerably reduced barrier to drug absorption through the skin of preterm newborn infants.

We thank Ms S Murdan, Ms $\mathrm{K}$ Lee, and Ms N Butler for technical assistance with the in vitro studies and Dr J Zuccollo for the provision of neonatal skin from cadavers.

1 Freeman JA, Doyle E, Im NT. Topical anaesthesia of the skin: a review. Pediatric Anaesthesia 1993; 3: 129-38.

2 Juhlin L, Evers H, Broberg FA. A lignocaine-prilocaine cream for superficial skin surgery and painful lesions. Dermatologica Scandanavia 1980; 60: 544-6.

3 Engberg G, Danielson S, Henneberg S, Nilsson A. Plasma concentrations of prilocaine and lidocaine and methaemaglobin formation in infants after epicutaneous application of a $5 \%$ lidocaine-prilocaine cream (Emla). Acta Anaesthesiol Scand 1987; 31: 624-8.

4 Barrett DA, Rutter N. Transdermal delivery and the premature neonate. Crit Rev Ther Drug Carrier Syst 1994 (in press).

5 Barrett DA, Rutter N, Davis SS. An in vitro study of diamorphine permeation through premature neonatal skin. Pharm Res 1993; 10: 583-7.

6 Barker N, Hadgraft J, Rutter N. Skin permeability in the newborn. $\mathcal{F}$ Invest Dermatol 1987; 88: 409-11.

7 McCormack J, Boisits EK, Fisher LB. An in vitro comparison of the permeability of adult versus neonatal skin. In: Maibach HI, Boisits EK, eds. Neonatal skin: structure and function. New York: Marcel Dekker, 1982: 149-64.

8 Wester RC, Maibach H. Comparative percutaneous absorption. In: Maibach HI, Boisits EK, eds. Neonatal skin: structure and function. New York: Marcel Dekker, 1982: 137-47.

9 Evans NJ, Rutter N. Development of the epidermis in the newborn. Biol Neonate 1986; 49: 74-80.

10 Rowland M, Tozer TN, eds. Clinical pharmacokinetics. USA: Lea and Febiger, 1989: 65-6.

11 Tucker GT, Mather LE. Clinical pharmacokinetics of local anaesthetics. Clin Pharmacokinet 1979; 4: 241-78.

12 Siddiqui O, Roberts MS, Polack AE. The effect of iontophoresis and vehicle $\mathrm{pH}$ on the in-vitro permeation of lignocaine through human stratum corneum. $₹$ Pharm
Phention Pharmacol 1985; 37: 732-5. 